\title{
アブミ骨筋腱骨性固着症の 2 症例
}

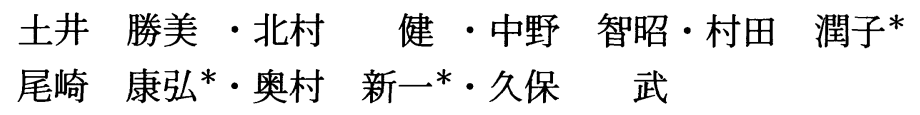

\section{Two Cases of Conductive Hearing Loss due to Ossification of the Stapedius Tendon}

\author{
Katsumi Doi, Ken Kitamura, Tomoaki Nakano and Takeshi Kubo \\ (Osaka University) \\ Junko Murata, Yasuhiro Ozaki and Shinichi Okumura \\ (Osaka Rosai Hospital)
}

\begin{abstract}
Two cases of conductive hearing loss due to ossification of the stapedius tendon are described. A woman, 24 years old, suffered from progressive, bilateral $(R>L)$ hearing loss from the age of sixteen and was referred to our office for advice regarding surgical treatment. The tympanic membrane, tympanogram and radiological examinations were normal on both sides, however, the pure tone audiogram (PTA) showed bilateral conductive hearing loss and the stapedial reflex had disappeared on both sides. A diagnosis of otosclerosis was made, and the patient was hospitalized for a stapedectomy. During surgery, the stapes on the right side was revealed to be immobile with fixation of the footplate as well as ossification of the stapedius tendon. A stapedectomy, combined with removal of the ossified stapedius tendon, was performed, and the PTA threshold improved to $21.3 \mathrm{~dB}$ from $47.5 \mathrm{~dB}$.

A man, 18 years old, was noticed to have bilateral conductive hearing loss at the age of six. A diagnosis of ossicular chain anomaly was made, and the patient subsequently underwent a hearing examination every year. The patient decided to undergo an exploratory tympanotomy at the age of seventeen. During surgery, the stapes on both sides was revealed to be fixed and showed no movability due to ossification of the stapedius tendon, fixation of the footplate, and an extra bony connection between the anterior crus of the stapes and the facial nerve canal. A stapedectomy combined with removal of two bony connections restored his hearing level to $15 \mathrm{~dB}$ from $48.8 \mathrm{~dB}$ on the right side and to $17.5 \mathrm{~dB}$ from $33.8 \mathrm{~dB}$ on the left side.
\end{abstract}

Key words : conductive hearing loss, stapedius tendon, stapedectomy, footplate, ossified

はじめに

アブミ骨筋腱の骨性固着あるいはアブミ骨上部構造と 周囲組織との骨性連結により，アブミ骨の可動性が制限 され，伝音性難聴を示す症例は極めてまれとされ，これ
までの報告例はわずかに25症例である1) 18). アブミ骨 底板固着症と同様に，アブミ骨筋腱の骨性固着に拉いて も，先天性拉よび後天性の原因によるものがそれぞれ推 察されている. 今回, 我々は, アブミ骨筋腱骨性固着と 
アブミ骨底板固着を同時に合併し，鼓膜正常ながら，伝 音性難聴を示した 2 症例にアブミ骨手術を施行し，良好 な聴力改善が得られたので報告する． 2 症例のらち， 1 例は後天性の, 1 例は先天性のアブミ骨筋腱骨性固着症 と推察された。

\section{症例}

症例 $1: 24$ 歳, 女性.

家族歷 : 詳細は不明であるが，母親と姉にも難聴があ る.

既往歴 : 特記すべきものなし.

現病歷 : 16 歳頃より両側の難聴を自覚し, 近医耳鼻咽 喉科を受診したところ, 純音聴力検査上, 気導一骨導差 を認め, 耳管狭窄症の診断にて通気治療など受けるも， 聴力の改善は認められず, その後放置していた. 24歳時, 難聴の進行により, 社会生活上不便となったため, 近医 耳鼻咽喉科より紹介受診となった. 両側鼓膜は正常で, ティンパノグラムは両側 $\mathrm{A}$ 型, アブミ骨筋反射は両側と も消失していた。純音聴力検查上, 平均聴力レベル右側 $47.5 \mathrm{~dB}$, 左側 $32.5 \mathrm{~dB}$ の混合性難聴を認めた(図 1 ). 耳硬化症の診断のもと, 平成 6 年11月 2 日, 全身麻醉下 に右アブミ骨手術を施行した。術中所見では, 鼓室内に 入ると，耳小骨の形態拉よび連鎖は正常と思われた. し かしながら，耳小骨連鎖の可動性が全く消失して拉り， 詳細に観察すると，アブミ骨筋腱が骨化して固着してい たのが判明したため，同部を注意深く削除した．さらに，

(24歳, 女性)

(R) stapedectomy 1994.11.2.

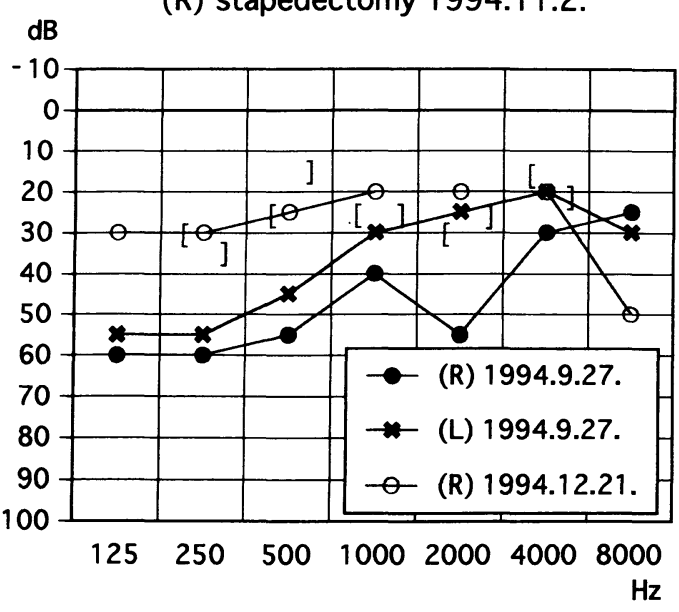

図 1 症例 1 の術前・術後の純音聴力検査結果
アブミ骨底板にも固着が認められ，アブミ骨の可動性が 回復しなかったため，アブミ骨を摘出して，耳介軟骨板 を用いたアブミ骨手術を施行して，手術を終了した(図 2 ). 右側の手術前後の純音聴力域値は, 術前 $47.5 \mathrm{~dB}$ から術後 $21.3 \mathrm{~dB}$ へと著明な聴力改善を認めた（図 1 ). 左側は， $32.5 \mathrm{~dB}$ の混合性難聴を示しているが， 1000 $\mathrm{Hz}$ 以上の高周波数域にて気導一骨導差を認めず, 現時 点では手術予定となっていない。

症例 $2: 18$ 歳, 男性.

家族歴・既往歴：特記すべきものなし.

現病歴：6歳時, 小学校入学時の検診にて両側難聴を 指摘され, 近医耳鼻咽喉科にて, 純音聴力検查上, 気導 一骨導差を認め, 滲出性中耳炎との診断にて加療を受け るも，聴力改善を認めず，当科紹介受診された．両側鼓 膜は正常で, 中耳奇形の診断にて, 年 1 回の純音聴力検 査にて経過観察を行っていた.17歳時, 純音聴力検査上,
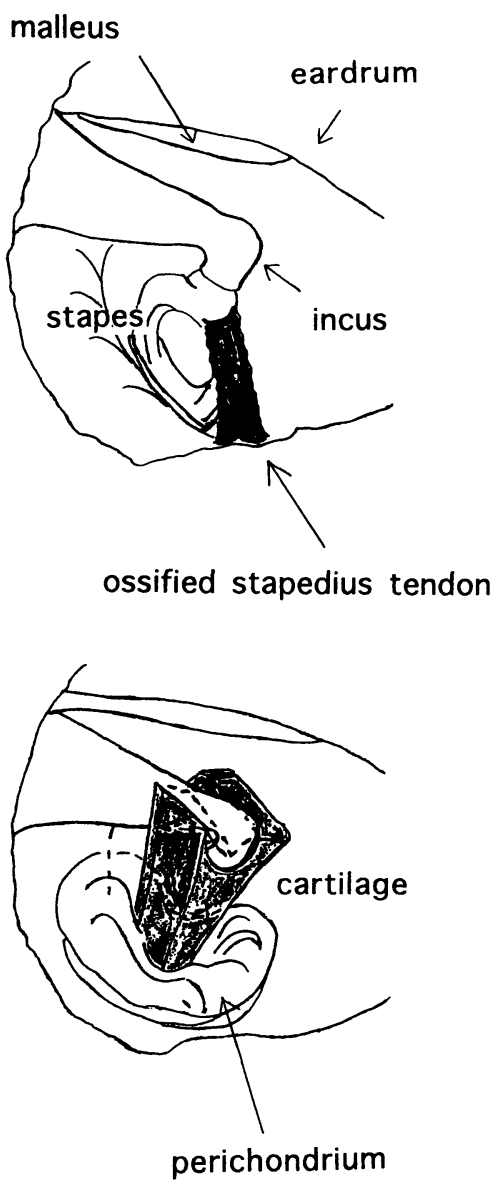

図 2 症例 1 の手術所見 
右平均聴力レベル右側 $48.8 \mathrm{~dB}$, 左側 $33.8 \mathrm{~dB}$ の伝音性 難㯖を認めた(図 3 ). 鼓膜所見は正常, ティンパノグラ ムは両側 $\mathrm{A}$ 型, アブミ骨筋反射は両側とも消失していた。 平成 7 年 6 月 2 日, 中耳奇形の䛦断にて, 全身麻酔下に 右アブミ骨手術を施行した。手術時の所見は，鼓室内に 入ると, キヌタ骨の長脚はやや変形するも, 耳小骨連鎖 は泳涪正常と思われた，耳小骨連鎖の可動性は全く消失 し, 詳細に観察していくと, アブミ骨筋腱が骨性に固着 すると同時に，アブミ骨前脚と顔面神経管との間に骨性 連結(骨橋)が存在し，これら 2 力所の骨性連絡によりア ブミ骨の可動性が障害されているのが判明した(図 4). 骨橋拉よび骨化したアブミ骨筋腱を注意深く削除したが, 症例 1 と同様に, アブミ骨底板にも固着が認められ，ア ブミ骨の可動性が回復しなかったため, アブミ骨上部構 造を摘出して, 底板に径約 $1 \mathrm{~mm}$ の開空を行った(図 5 ). 径 $0.6 \mathrm{~mm}$, 長さ $4.0 \mathrm{~mm}$ のテフロンワイヤーピストン を挿入してキ又タ骨に装着し，ピストン周囲に結合織を シールして，アブミ骨手術を終了した(図6). 右側の手 術前後の純音聴力域値は, 術前 $48.8 \mathrm{~dB}$ から術後 11.3 $\mathrm{dB}$ 一之著明な聴力改善を認めた（図 3 )。左側は，平成 8 年 8 月 16 日に全身麻酔下にて左アブミ骨手術を施行し た。手術中の所見は右側と同様であり，アブミ骨筋腱が 骨性に固着すると同時に, アブミ骨前脚之顔面神経管と の間比骨性連結(骨橋)が存在し，これら 2 力所の骨性連 絡によりアブミ骨の可動性は障害されていた(図 7 )。骨

(18歳, 男性)

(R) stapedotomy 1995.6.2.

(L) stapedectomy 1996.8.16.

$\mathrm{dB}$

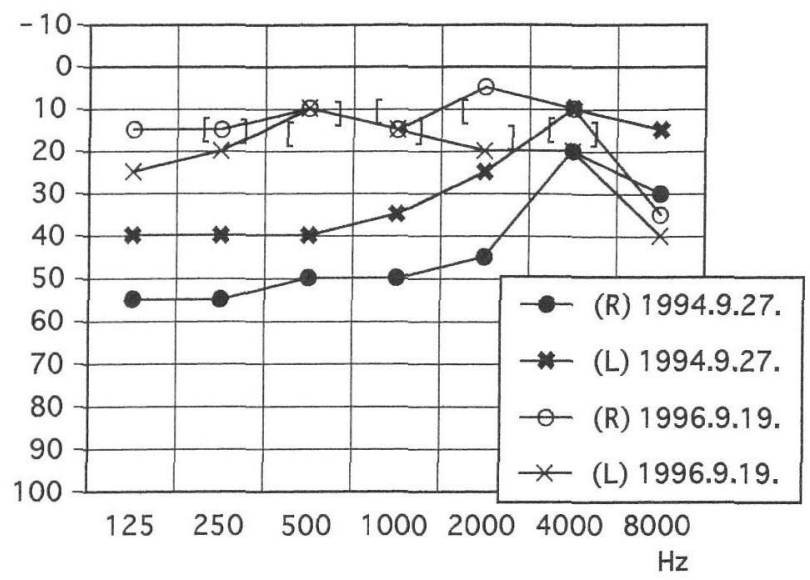

図 3 症例 2 の術前・術後の純音聴力検查結果
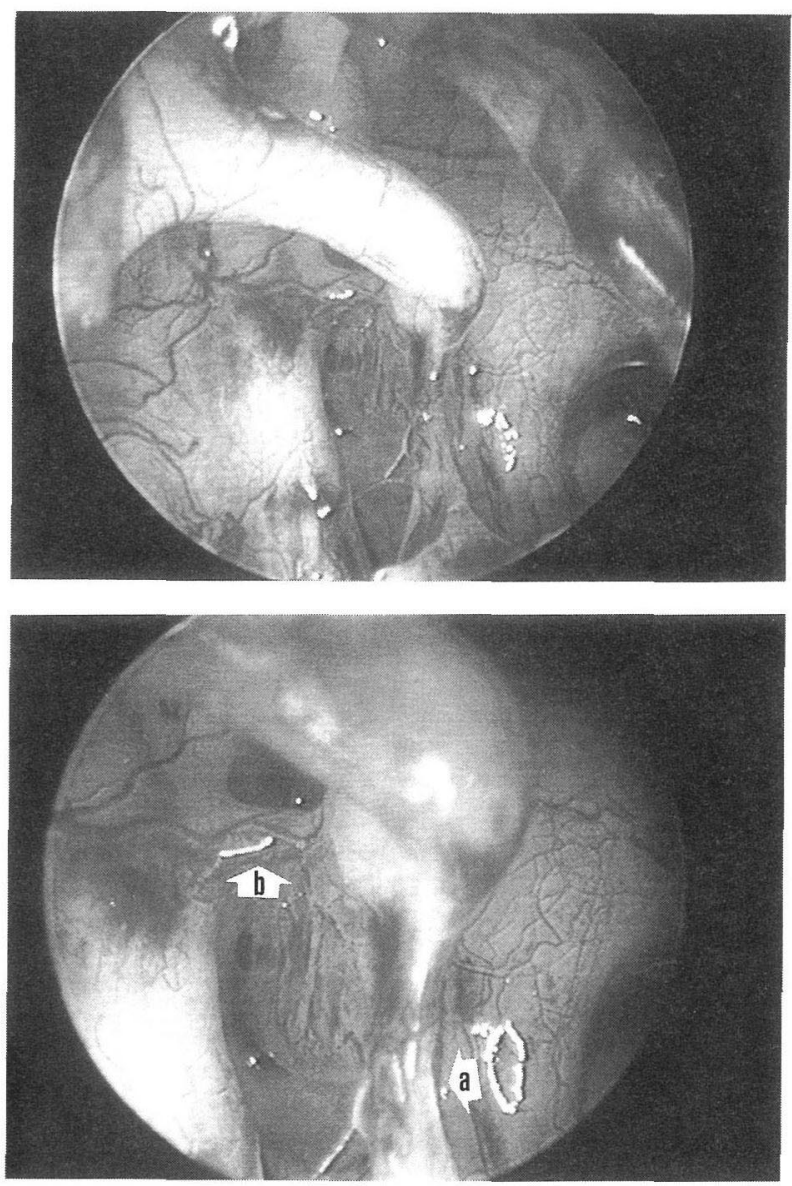

図4 症例 2 の内視鏡下手術所見

アブミ骨管腱の骨性固着 (矢印a)と, それとは別にアブ ミ骨前脚と顔面神経管との間に骨性連結(矢印 b ) 認め る.

橋掞よび骨化したアブミ骨筋腱を注意深く削除したが， 症例 1 と同様に, アブミ骨底板にも固着が認められ，ア ブミ骨の可動性が回復しなかったため, アブミ骨上部構 造怙よびアブミ骨底板を摘出し, 径 $0.6 \mathrm{~mm}$, 長さ 4.0 $\mathrm{mm}$ のテフロンワイヤーピストンを挿入してキヌタ骨に 装着し，ピストン周囲に結合織をシールして，アブミ骨 手術を終了した。左側の手術前後の純音聴力域値は, 術 前 $33.8 \mathrm{~dB}$ から術後 $15 \mathrm{~dB}$ へと著明な聴力改善を認め た(図 3 ).

\section{考察}

鼓膜正常で伝音性難聴を示す中耳奇形のうち，先天性 アブミ骨固着症はしばしば遭遇するものの 1 つであり, 当科の過去 10 年間の中耳奇形 32 症例中にも 4 例(約 $13 \%$ ) 

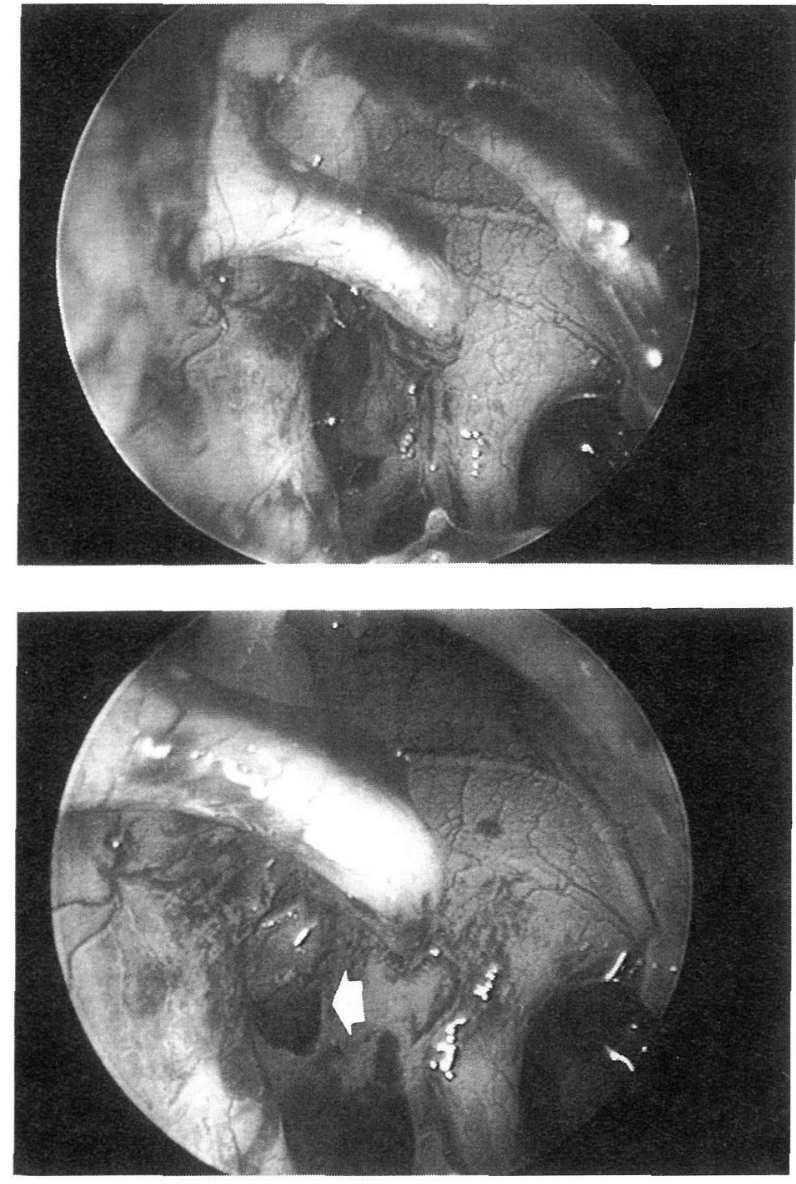

図 5 症例 2 の内視鏡下手術所見

2 力所の骨性連結を除去して, 底板固着により不動のア ブミ骨上部構造を摘出し(上), 底板に開空する(失印) (下).

の先天性アブミ骨固着症が含まれていた，先天性アブミ 骨固着症は，大部分がアブミ骨底板の固着であり，アブ ミ骨筋腱の骨性固着を伴ら症例，あるいは，アブミ骨筋 腱骨性固着が単独で存在する症例は極めてまれである. 我々が文献的に検索した限り，これまでの報告例は， 1957年の Schuknecht らの最初の報告例に始まり今回の 2 症例を含めて27例である1) 18).

表 11) 18) にこれまでの報告例をまとめてあるが，年 齢は 5 歳より 59 歳まで幅広く分布している。平均年齡は 25.6歳で，これは原因として先天性と推察されるものが 多く $(70 \%)$ 含まれていることに起因するものと推察され る。男性：女性は 10：16 とやや女性に多い傾向がみら れる。アブミ骨筋腱固着は，手術で確認した24症例中15
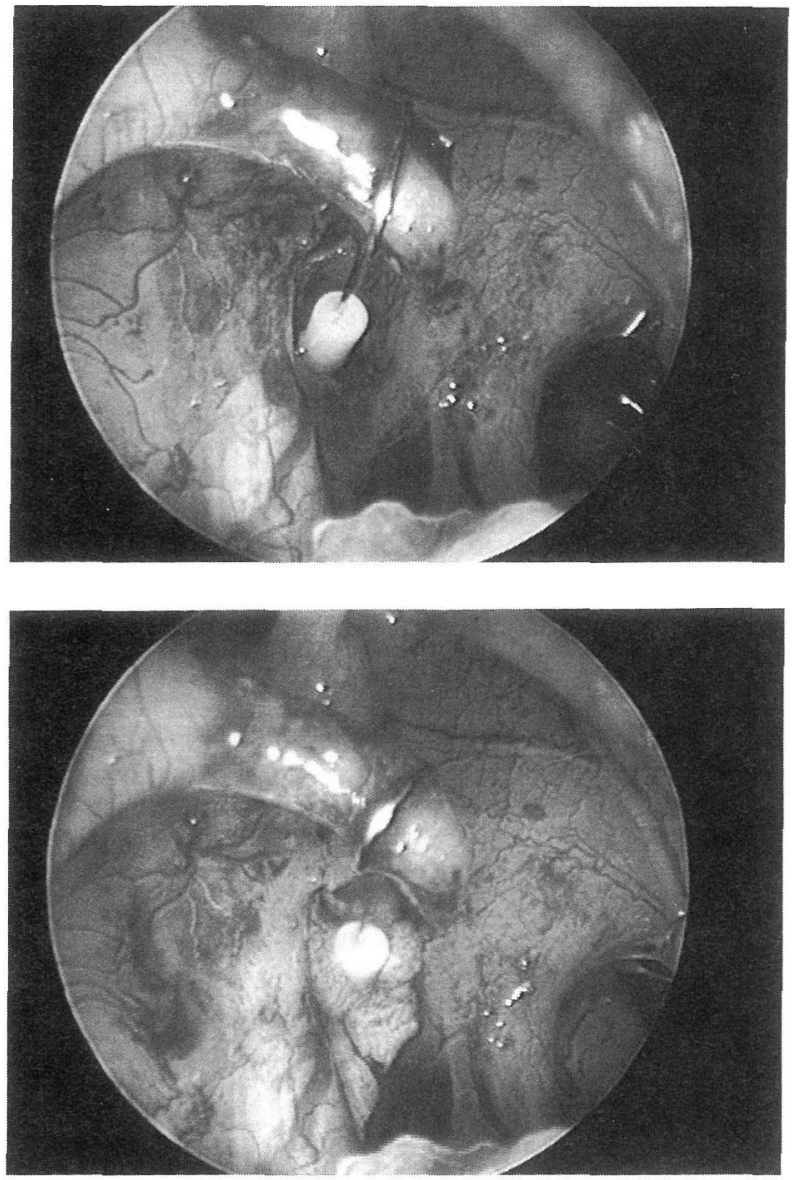

図 6 症例 2 の内視鏡下手術所見

テフロンワイヤーピストンを内耳へ挿入しキヌタ骨に装 着する(上)。ピストン周囲は結合織にて閉鎖する(下)，

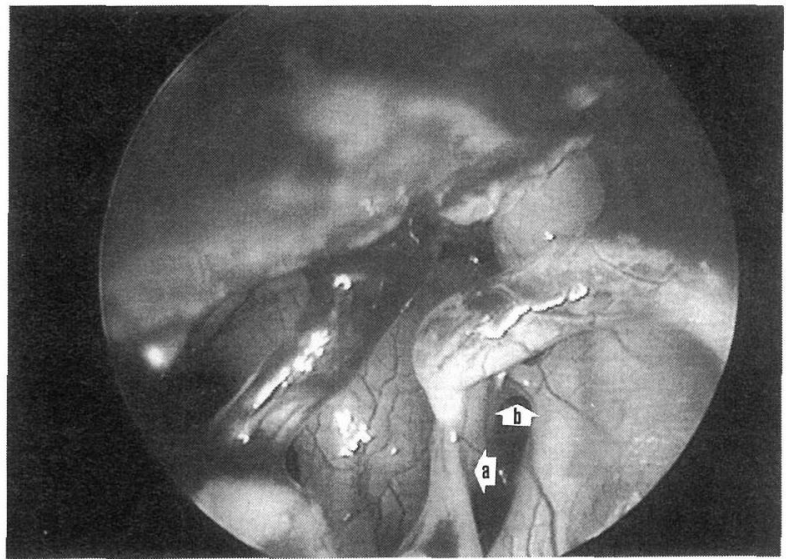

図 7 症例 2 の内視鏡下手術所見

アブミ骨筋腱の骨性固着(知印ａ）と，それとは別にアブミ 骨前脚と顔面神経管との間深骨性連結(矢印b)を認める。 
表 1

\begin{tabular}{|c|c|c|c|c|c|}
\hline 報告 & 年度 & 年齢・性別 & S. T. 骨性固着 & 中耳の異常 & 原 因 \\
\hline Schuknecht $5^{1)}$ & 1957 & 55 - 女性 & 左 & 無 & P.E. 過長 \\
\hline Henner $^{2)}$ & 1960 & $?$ & $?$ & 無 & 先天性 \\
\hline Podoshin $5^{3)}$ & 1972 & 15·男性 & 両 & 無 & 先天性 \\
\hline Patel $^{4)}$ & 1972 & 39 - 女性 & 右 & アブミ骨底板固着 & 耳硬化症 \\
\hline Wardale ${ }^{5)}$ & 1973 & $17 \cdot$ 女性 & 両 & 無 & 先天性 \\
\hline Meuser $\left.^{6}\right)$ & 1977 & $46 \cdot$ 女性 & 両 & 無 & 後天性 \\
\hline \multirow[t]{2}{*}{ 松元 57) } & 1980 & 22 - 女性 & 両 & $\begin{array}{l}\text { 無 } \\
\end{array}$ & 先天性 \\
\hline & & 17 -女性 & 左 & アブミ骨底板固着 & 先天性 \\
\hline \multirow[t]{2}{*}{ 西村 58) } & 1982 & 24 - 男性 & 両 & キヌタ骨奇形 & 先天性 \\
\hline & & $18 \cdot$ 男性 & 両 & 無 & 先天性 \\
\hline Cremers $5^{9)}$ & 1986 & $12 \cdot$ 女性 & 両 & 無 & P.E. 過長 ? \\
\hline 松元 $5^{10)}$ & 1987 & 59 - 男性 & 両 & 無 & 後天性 \\
\hline \multirow[t]{2}{*}{ 加賀 $5^{11)}$} & 1990 & 40 ・男性 & 両 & 右アブミ骨底板固着 & 先天性 \\
\hline & & $59 \cdot$ 女性 & 右 & 無 & 先天性 \\
\hline \multirow[t]{2}{*}{ Grant $5^{12)}$} & 1991 & $9 \cdot$ 女性 & 両 & 無 & 先天性 \\
\hline & & 22 ·男性 & 両 & 無 & 先天性 \\
\hline \multirow[t]{2}{*}{ 加我 $5^{13)}$} & 1992 & 7 - 女性 & 両 & 無 & 先天性 \\
\hline & & 14·男性 & 両 & 無 & 先天性 \\
\hline \multirow[t]{2}{*}{ Jecker $5^{15)}$} & 1992 & 43 ·男性 & 右 & 無 & 先天性 \\
\hline & & $45 \cdot$ 女性 & 右 & 無 & 後天性 \\
\hline 西崎 ら ${ }^{16)}$ & 1993 & $6 \cdot$ 女性 & 両 & 無 & 左 P.E. 過長 \\
\hline \multirow[t]{2}{*}{ Kinsella $5^{17)}$} & 1993 & $26 \cdot$ 女性 & 両 & 無 & 先天性 \\
\hline & & $5 \cdot$ 女性 & 右 & 無 & 先天性 \\
\hline 朝蔭 ら ${ }^{18)}$ & 1994 & $10 \cdot$ 女性 & 右 & キヌタ骨奇形 & 先天性 \\
\hline 高松 ら ${ }^{14)}$ & 1995 & 14 - 男性 & 左 & アブミ骨底板固着 & 先天性 \\
\hline 症例 1 & 1996 & $24 \cdot$ 女性 & 右 & アブミ骨底板固着 & 耳硬化症 \\
\hline 症例 2 & & 18・男性 & 両 & アブミ骨底板固着 & 先天性 \\
\hline
\end{tabular}

S. T. : stapedius tendon

P. E. : pyramidal eminence

例は両側性であり, 我々の 2 症例でも難聴そのものは両 側性にあり, 症例 1 では確認できていないが, 症例 2 で は両側性にアブミ骨筋腱固着の存在が確認された.

アブミ骨筋腱骨性固着以外の耳小骨異常に関しては, 27 症例中 21 例 $(78 \%)$ ではアブミ骨筋腱固着のみで, 同部 を削除することにより，正常のアブミ骨の可動性が得ら れたと報告されている. 但し，この内 2 例でキヌタ骨長
脚に欠損が認められている8)。 アブミ骨底板固着を伴っ たものは, 今回の 2 症例を含めて 6 例めり， 4 症例では 幼少時よりの非進行性の難聴であることから, 先天性ア ブミ骨固着症にアブミ骨筋腱骨性固着を合併したものと 推察される. 他の 2 症例では, いずれも成人後に徐々に 進行する伝音性 (混合性) 難聴であることより耳硬化症の 診断がなされ4)，それにアブミ骨筋腱骨性固着を合併し 
たものと推察される.

アブミ骨䇗腱骨性固着の原因が何であるかとの明確な 決定は，しばしば非常に困難であり，主として病歷によ り先天性・後天性の診断が成されることが多い，後天性 のアブミ骨筇腱骨性固着症では，1)耳硬化症に合併す るもの4)，2 ) 異所性骨化によるもの6)10)，3 ）炎症による もの 15$) ４$ )錐体隆起の骨過長によるもの19916) が推察さ れている.

耳硬化症に合併する場合には，1)アブミ骨筋腱まで 硬化病変が及んだか，2)不動化したアブミ骨およびア ブミ骨筋腱に抽いて異所性骨化が発生した可能性が考兄 られる，欧米に打ける耳硬化症では，硬化病巣の高度発 育により，アブミ骨筋腱にその硬化病変が及ぶことは十 分可能であろ54). 本邦での耳硬化症に扔いては，その ような高度の硬化病变は比較的まれであり，今回の症例 1 と颃いても，アブミ骨底板の輪状勒帯前方を含めて, アブミ骨周囲にまで発育する硬化病巣は観察されなかっ た. また，削除・摘出した骨化アブミ骨筋腱が非常に小 さいこともあり, 同組織に耳硬化症の病変が存在してい たかどうかの病理学的検索は行い得ていない. 従って, 現病歴より, 耳硬化症に合併したアブミ骨筋腱骨性固着 症との診断がなされたに過ぎない。

異所性骨化の原因として, 局所の血流不全・低酸素状 態・浮腫などによる静脈血のらっ滞および $\mathrm{Ca}^{2+}$ の異常 沈着が推定されている. 文献的には, 異所性骨化との関 連で，全身の勒帯硬化症・糖尿病による新陳代謝障害な ぞの存在が促進的に作用した可能性が推論されている が10), また, 局所の炎症が異所性骨化の原因・誘因之 なることに関しては, 鼓室硬化症の発症からも理解され 易い15)。しかしながら，アブミ骨の底板固着を伴う場合 には, 同様の理由で, これらが耳硬化症に合併したもの ではないとする確実な証拠を見つけるのは困難である.

1957年に Schuknecht ら ${ }^{1)}$ が報告した症例では, 錐体 隆起の骨過長によりアブミ骨の可動性が制限されており, この骨組織を削除すると下方に正常のアブミ骨笳腱が観 察されている1)。同様の報告もあり，後天性アブミ骨筋 腱骨性固着症の原因の 1 つとして考慮されるべきもので ある. 今回の 2 症例では, いずれも, 骨性固着部の下方 にアブミ骨筋腱は認められなかった。

アブミ骨筋腱骨性固着症が先天性と診断されるのは, 鼓膜正常で, 中耳炎などの既往がなく, 小児期より存在 する非進行性の伝音性難聴がある場合である.アブミ骨
筋腱およびアブミ骨筋はともに第 2 鰓弓より発生するが, それぞれ母細胞は異なって和り, interhyale拈よび blastema cells からの分化とされている. 胎生 $7 \sim 10$ 週 にかけて, 顔面神経管の形成・骨化, Meckel, Reichert 軟骨よりの耳小骨の形成・骨化，とほぼ同時期に， アブミ骨筋腱もまた形成されるが，何らかの分化・骨化 段階での異常により, アブミ骨筇腱骨性固着症が発症す るものと推察される. 症例 2 の如く, 骨化したアブミ骨 筋腱以外飞, 顔面神経管など周囲組織と骨性連絡 (骨橋) を伴った例も他に報告されて打り5)17)，いずれも先天性 アブミ骨筋腱骨性固着症との診断がなされている.

\section{まとめ}

1 ） アブミ骨筋腱骨性固着症の 2 症例に対してアブミ 骨手術と骨性固着筋腱除去術を行い良好な聴力改善が得 られた。

2 ) 症例 1 は後天性で, 耳硬化症によるアブミ骨の可 動性低下により異所性骨化が起こったものと推察した。

3 ) 症例 2 は先天性で, アブミ骨筋腱骨性固着にアブ ミ骨前脚一顔面神経管の骨性連結を合併したものと推察 した.

本論文の要旨は第 58 回耳鼻咽喉科臨床学会 (1996年 6 月 28 日, 名古屋)にてロ演発表した.

\section{参考文献}

1) Schuknecht HF and Trupiano $\mathrm{S}:$ Some interesting middle ear problems. Laryngoscope $67: 395 \sim 409,1957$.

2 ) Henner R : Congenital middle ear malformations. Arch Otolaryngol $71: 454 \sim 458,1960$.

3 ) Podoshin L, Fradis M, Zisman D, et al : Congenital anomalies of the stapes. Arch Otolaryngol $96: 254 \sim 255$, 1972.

4) Patel $\mathrm{KN}:$ Ossification of the stapedius tendon. J Laryngol Otol $86: 863 \sim 865,1972$.

5 ) Wardale A : Clinical records; bilateral otosclerosis of the stapedius tendon. J Laryngol Otol 87 : 1225 1227, 1973.

6 ) Meuser $\mathrm{W}:$ Schalleitungsschwerhörigkeit durch verknöcherte Stapediussehnen. Laryngol Rhinol $56: 12 \sim 13,1977$.

7 ）松元一郎, 高橋政見, 岡田修一, 他 : アブミ骨笳腱骨性固 着を示した先天性耳小骨奇形. 臨床耳科 $7: 20 \sim 21,1980$.

8 ）西村武重, 伊達敬一, 斎藤 章, 他 : アブミ骨笳腱骨性固 着による伝音性難聴の 2 症例. 臨床耳科 9 ：144 145, 1982.

9) Cremers CWRJ and Hoogland GA : Congenital stapes 
ankylosis by elongation of the pyramidal eminence. Ann Otol Rhinol Laryngol 95 : 167 168, 1986.

10）松元一郎, 東野哲也, 宮永 敏 : 耳硬化症を疑わせた後天 性アブミ骨筋腱骨性固着症例. 臨床耳科 $14: 346 \sim 347$, 1987.

11）加賀達美, 新川 敦, 木村栄成, 他: アブミ骨筋腱骨性固 着の 2 症例. 耳喉頭頸 $62: 1085 \sim 1088,1990$.

12) Grant WE and Grant WJ : Stapedius tendon ossification ; a rare cause of congenital conductive hearing loss. J Laryngol Otol $105: 763 \sim 764,1991$.

13）加我君孝, 原 誠, 中村直也 : 先天性中耳奇形「アブミ 骨筋腱の骨化症の 1 例」. Otol Jpn $2:$ 495, 1992.

14）高松一郎, 小河良昇, 長原太郎：あぶみ骨筋腿骨化を伴っ た中耳奇形 2 例. 耳鼻 $41: 61 \sim 65,1995$.

15) Jecker $P$ and Harwein $J$ : Die Verknöcherung der
Stapediussehne als seltene Ursache einer Schalleitungsschwerhörigkeit. Laryngol Rhinol Otol $71: 344 \sim 346$, 1992.

16）西崎和則, 増田 游, 林 真美, 他 : 鼓室後壁とアブミ骨 が骨性固着を呈した先天性両側中耳奇形の一症例. 耳鼻臨 床補64:102 105, 1993.

17) Kinsella JB and Kerr AG : Familial stapes superstructure fixation. J Laryngol Otol $107: 36 \sim 38,1993$.

18）朝蔭孝宏, 船井洋光, 北原伸郎, 他 : アブミ骨筋腿骨性固 着症例. 耳鼻臨床 $87: 1639 \sim 1642,1994$.

$\left(\begin{array}{l}\text { 原稿受付: 平成 } 8 \text { 年 } 12 \text { 月 } 27 \text { 日 } \\ \text { 原稿採択 : 平成 } 9 \text { 年 } 4 \text { 月 } 2 \text { 日 } \\ \text { 別刷請求先 : 土井勝美 } \\ \text { † } 565 \text { 吹田市山田丘 } 2-2 \\ \text { 大阪大学医学部耳鼻咽喉科学教室 }\end{array}\right)$

